\title{
Archipel
}

A RCHIPEL Études interdisciplinaires sur le monde insulindien

$101 \mid 2021$

Varia

\section{The Contribution of Archipel to the Knowledge of Insulindian Chinese (1971-2020) Some Key Topics}

La contribution d'Archipel à la connaissance des Chinois d'Insulinde (1971-2020)

$\Leftrightarrow$ Quelques sujets clés

\section{Claudine Salmon}

\section{Édition électronique}

URL : https://journals.openedition.org/archipel/2395

DOI : 10.4000/archipel.2395

ISSN : 2104-3655

Éditeur

Association Archipel

Édition imprimée

Date de publication : 30 June 2021

Pagination : $57-84$

ISBN : 978-2-910513-85-6

ISSN : 0044-8613

\section{Référence électronique}

Claudine Salmon, «The Contribution of Archipel to the Knowledge of Insulindian Chinese (1971-2020)

Some Key Topics », Archipel [En ligne], 101 | 2021, mis en ligne le 12 juin 2021, consulté le 02 juillet 2021. URL : http://journals.openedition.org/archipel/2395 ; DOI : https://doi.org/10.4000/archipel. 2395 


\section{The Contribution of Archipel to the Knowledge of Insulindian Chinese (1971-2020) - Some Key Topics}

\section{Introduction}

European travelers took an early interest in the Chinese they encountered in the South Seas, as is apparent from their travelogues. ${ }^{1}$ Insulindia-based civilian administrators and missionaries were among the first authors to examine the Chinese presence in the region and to produce scientific and practical studies, the latter aimed at solving the problems they were faced with. Some of these studies were published in journals devoted to these countries, one of the oldest being the Verhandelingen van het Bataviaasch Genootschap van Kunsten en Wetenschappen (hereafter $V B G K W$ ) or "Transactions of the Batavian Society of Arts and Sciences," founded in 1778. The French, though not yet settled in Southeast Asia, were nevertheless interested in the Chinese established within the region, as evidenced by the publication of articles in scholarly journals, such as the translation by a certain C. M. of Jan Jacob Vogelaar's report on the Feast of the Dead, Qingming 清明, as observed in Batavia on April 4, 1789 in the Wanjie si 萬劫寺. This report was published in the newly founded Journal Asiatique

\footnotetext{
* CNRS, Paris.
}

1. Such as the Jesuit Guy Tachard (1648-1712) who relates his encounter with the Chinese in a cemetery of Batavia, and the hydrographic engineer and explorer François Froger (born in 1676) who left valuable notes on the first Ming loyalists he met in Malacca. 
(Vol. 2, April 1823, p. 236-243). ${ }^{2}$ Four years later, an article by the British missionary and sinologist Walter Henry Medhurst (1796-1857) on the Chinese New Year Festival in Batavia appeared in Nouvelles annales des voyages et des sciences géographiques (26 livr. $2^{\mathrm{e}}$ série, Juillet-Septembre 1827, p. 225-227). The Annales de l'Extrême-Orient (Vol. 3, 1880-1881, p. 225-240) published the translation of one of the rare articles by Johannes Eduard Albrecht (1838-1890, one of the two first interpreters of the Chinese language, appointed in the Indies in 1860$)^{3}$ on primary education among the Chinese of Java. However, such contributions remained rather rare in French periodicals during the $19^{\text {th }}$ century.

The foundation in 1889 of the Dutch-French journal T'oung Pao 通报 ${ }^{4}$ by Gustave Schlegel (of German origin, 1840-1903), prof. of Chinese at Leiden University) and Henri Cordier (1849-1925, prof. of History and Geography at the École spéciale des langues orientales vivantes in Paris) offered the hope that studies on the languages and peoples of East Asia would develop along new lines. As a matter of fact, Gustave Schlegel, after having studied in China, was appointed as one of the two first interpreters in Batavia in 1862. He remained in the Netherlands Indies until 1872, and the following year began to teach Chinese in Leiden. As a matter of fact, Schlegel was the first sinologist who took an interest in Insulindian Chinese culture, and who had a certain knowledge of Malay. ${ }^{5}$ In the first two volumes of T'oung Pao, he published five studies: the first gives the Hokkien text of a philippic written in verse by a certain TanIok-Po 陳育報 on Chinese Captain Li-Khi-Thai 呂崎太 (1866), along with a German translation; with this he initiated research on Chinese literature outside China; the second (unfinished), which provides a series of signboards and house sentences collected in Java with Malay translations made locally and his own translations with commentaries in English; the third, on Chinese loan-words in Malay/Indonesian, marks the beginning of research in that field. ${ }^{6}$ In the

2. The original in Dutch first appeared in the $V B G K W$ (Vol. VI, 1792, p. 1-14).

3. He was appointed in Muntok (Bangka), see Pieter Nicolaas Kuiper, The Early Dutch Sinologists. A Study of their Training in Holland and in China and their Functions in the Dutch Indies, PhD Leiden University, Leiden 2015, Part II, Appendix A, Biographies and Bibliographies of the Sinologists, p. 828-831.

4. Full name: T'oung Pao 通报, Archives pour servir à l'étude de l'histoire, des langues, de la géographie et de l'ethnographie de l'Asie orientale (Chine, Japon, Corée, IndoChine, Asie centrale et Malaisie), or « Archives for the Study of the History, Languages, Geography and Ethnography of East Asia (China, Japan, Korea, Indo-China, Central Asia and Malaya. ». From 1906 onwards, the list of countries is suppressed.

5. See Kuiper, The Early Dutch Sinologists, Part II, Appendix A, p. 915-923.

6. G. Schlegel, "Philippica des Chinesen Tan-Iok-Po gegen den Kapitän der Chinesen Li-Ki-Thai," T'oung Pao I (1890), p. 29-41; of the same, "On Chinese Signboards and House-sentences", op. cit., p. 118-136; of the same, "Chinese Loanwords in the Malay Language", op. cit., p. 391-405. For an impressive continuation, see Russell Jones, Chinese Loan-Words in Malay and Indonesian. A Background Study, Kuala Lumpur, 
two others, he drew attention to translations of Chinese fiction into Malay and Javanese, as well as to a Sino-Indonesian calendar. ${ }^{7}$

Several years later, J. W. Young (of British origin, 1855-1898) paved the way for epigraphic studies with his article in French on a $19^{\text {th }}$-century inscription located near the cave dedicated to the eunuch Sanbao 三寶 (Semarang). ${ }^{8}$ However, not many of the interpreters who succeeded them wrote for T'oung Pao, preferring, it seems, to publish in Dutch journals devoted to the colony, ${ }^{9}$ and eventually in journals on China published in Hong Kong, as did some Dutch educated Peranakan journalists who wrote on the culture of their own community, such as the journalists and writers Kwee Kek Beng (1900-1975) and Nio Joe Lan (1904-1973). ${ }^{10}$

For their part, the French sinologists who became interested in the Chinese communities of Indochina, such as Émile Gaspardone (1895-1982), tended to publish in Journal Asiatique, Bulletin de l'École française d'Extrême-Orient (BEFEO), Sinologica, and a few other reviews. Thus, the opportunity for T'oung Pao to deal with Chinese outside China, in Indochina and Insulindia in particular, was practically lost. Even though, since the late 1960s, European scholars started to investigate Southeast Asian Chinese because they could no longer travel to China to conduct research, very few articles on the subject were published in this journal. ${ }^{11}$ In other words, sinology has remained essentially understood to be within China's political borders.

The creation of Archipel, which proposed to publish chronicles, studies, and especially documents and "dossiers thématiques" on the Insulindian world, was to become a platform for cultural and historical studies on various Chinese communities of the Indonesian archipelago, the Malay peninsula and Singapore, and to a lesser extent the Philippines, so to say on the fringes of

University of Malaya Press, 2009 (review in Archipel 59, p. 223-224).

7. G. Schlegel, "Chinese-Malay and Javanese Literature in Java", T'oung Pao, II (1891), p. 148-151; of the same, "Un calendrier indonésien-chinois", T'oung Pao, II (1891), p. 175-177.

8. J.W. Young, « Sam Po Tong. La grotte de Sam Po », T’oung Pao, IX (1898), p. 93-102.

9. For more details on their publications, see Kuiper, The Early Dutch Sinologists, Part II, Appendix A. Biographies and Bibliographies of the Sinologists. It is worthy of note that one of the first studies on the legal statute of the Chinese in the Netherlands Indies by a Dutch civil servant (J.J. Meijer, « La condition politique des Chinois aux Indes néerlandaises ») appeared in T'oung Pao IV (1893), p. 1-32; 137-173.

10. See C. Salmon, Literature in Malay by the Chinese of Indonesia. A provisional annotated bibliography, Paris, Editions de la Maison des Sciences de l'Homme, 1981, p. 202-203; 258-261.

11. Although one article on the history of the Chinese community of Makassar by $\mathrm{C}$. Salmon was published in 1969 in T'oung Pao (Vol. LV, 4-5, p. 241-297). 
the mainstream of Anglo-Saxon research that started in the late 1950s. ${ }^{12}$ Since 1971, slightly more than one hundred studies have been published that for the most part deal with literary and historical matters. They emanate from Western scholars, especially French coming from various backgrounds, which constitutes a novelty, but also from researchers from Indonesia, Malaysia, Singapore, the Philippines, as well as from Mainland China, altogether about fifty. Some of these authors are historians, archaeologists, museologists, anthropologists, political scientists, while others are specialists of Chinese and Malay/Indonesian languages and literatures.

Some eleven thematic "dossiers" on Insulindian Chinese were designed between 1977 and 2016 (Vol. 14, 22, 28, 32, 43, 48, 68, 72, 77, 82, 92), bringing together from two to seven articles. However, some other articles dealing with Chinese matters may have been regrouped in other dossiers as well, such as "Techniques et Histoire" (Vol. 26), which includes two articles on Chinese ceramic factories in West Kalimantan and East Malaysia, "Littérature malaysienne", with an article on modern Chinese poetry (Vo. 19), "Littératures régionales" (Vol. 34), which contains two articles on Sino-Sundanese and Sino-Javanese literatures; or "De Singapour à Saïgon" (Vol. 43), which gathers three texts related to a travelogue by a Baba from Singapore. Only the last dossier, which in fact constitutes a special issue of Archipel, "Chinese Deathscapes in Insulindia," is the result of a workshop entitled "Death, burial rituals, and cemeteries among Chinese communities in Insular Southeast Asia (16/1 $7^{\text {th }}-21^{\text {st }}$ centuries)" that was organised by Teresita Ang See, Catherine Guéguen and C. Salmon, and convened in Manila by Kaisa Heritage Foundation on August 5, 2015.

Here, we intend to reflect for a moment on these fifty years of research that although not planned, have taken on a meaning that has gradually emerged over the years. Although research has been carried out in the context of all Insulindia, a large majority is focused on Java, where the Chinese community has a long and tumultuous history. This explains why we will first examine the impact of the political situation in Indonesia on the delineation of the main research fields over time. It goes without saying that historians working on the basis of sources held in public libraries and archives in Europe did not suffer from the local political situation, such as Leonard Blussé (Vol. 18, 58), Marie-Sybille de Vienne (Vol. 22), and Mary Somers Heidhues (Vol. 77).

Then, we will arbitrarily elaborate on a certain number of key themes for which the research carried out since 1971 has been particularly rewarding, such as the participation of the Chinese in Insulindian literature, the

12. See the appended list. For a comparison with the way studies on Indonesian Chinese were constituted and developed in the United States, other Anglo-Saxon countries, and elsewhere after the Second World War, see Mary Somers Heidhues, "Studying the Chinese in Indonesia: A Long Half-Century," SOJOURN: Journal of Social Issues in Southeast Asia, Vol. 32, No. 3 (2017), p. 601-633. 
elaboration of an Insulindian literature in Chinese, the role of women in the making of Peranakan communities, technical knowledge, trade and transfers, the circulation of medicinal and pharmaceutical knowledge, the place of the dead in the world of the living, and the discreet elaboration on the concept of Indonesian cultural heritage avant la lettre.

It goes without saying that it is not possible in this article to give an account of the great variety of the subjects dealt with during these past fifty years. The reader can nevertheless get an idea of this by perusing the bibliography appended to this article.

\section{Political Contexts and Main Research Fields over Time}

Denys Lombard and Claudine Salmon were among the first European students who, after the fall of Sukarno in 1965, settled in Jakarta for their research (1966-1969). The political situation was rather tense. Chinese characters had been prohibited in public places, schools and newspapers using Chinese language ${ }^{13}$ were closed, as were bookshops selling books published in that language, and Chinese associations, except those dealing with religious matters, were banned. These various prohibitions lasted until after the fall of President Soeharto in 1998.

The atmosphere of suspicion that prevailed within Indonesian society at that time explains why D.L. and C. S. initially focused their research on writings in Malay-Indonesian that could easily be consulted in public libraries. It turned out that the volume of this corpus was huge and varied (including texts in Javanese, Sundanese, Makassarese...), which led them to spread their investigation over several years on Insulindian Chinese literatures and Sino-Malay press and printing, and to invite other researchers to join them, among others: John B. Kwee (Vol. 19), Gilbert Hamonic (Vol. 26), Liang Liji 梁立基 (Vol. 34), Dédé Oetomo (Vol. 34), Faye Yik-Wei Chan (Vol. 42, 48), Myra Sidharta (Vol. 48), Monique Zaini Lajoubert (Vol. 48), Peter Worsley (Vol. 68), Elizabeth Chandra (Vol. 82), Yerry Wirawan (Vol. 82), and Song Ge 宋鴿 (Vol. 93, 97).

Simultaneously, but on a smaller scale, research was carried out on literature in Chinese emanating either from newcomers or from descendants of Chinese that was kept outside of Indonesia, in various public libraries in Japan, Singapore, Netherlands, Thailand and Malaysia. This research was carried out by scholars from France, Malaysia, Singapore, the Netherlands, and Hong Kong: Ho Khai-leong (Vol. 19), Brigitte de Beer-Luong (Vol. 23), Yu Wang Luen 俞王綸 (Vol. 24), Wong Seng-tong (Vol. 28), David K.Y. Chng 莊欽永 \& C. S. (Vol. 43), C. S. \& Ta Trong Hiêp 謝仲俠 (Vol. 47), Chen Jiarong 陳佳榮 (Vol. 52), C. S. (Vol. 56), and Pieter Nicolaas Kuiper (Vol. 77).

13. Except for Harian Indonesia / 印度尼西亞日報, a newspaper controlled by the Indonesian state. 
Finally, as a counterpoint, a few studies on English-language literature should be mentioned: those by K.S. Maniam (Vol. 19), and Neil Khor (Vol. 74) that deal with Malaysian Chinese authors, and that by Myra Sidharta (Vol. 24), about Queeny Chang (1896-1996), the only woman writer from Sumatra to have written her memoirs in English (Vol. 25). ${ }^{14}$

In the mid-1970s, the Archaeological Service of the Republic of Indonesia, then named Dinas Purbakala Republik Indonesia, showed an interest in the old site of Banten or Banten Lama, and at the instigation of its chief, Ms. Satyawati Suleiman (1920-1988) and Mr. Tjandrasasmita (1930-2010), Head of Islamic Archaeology, excavations were undertaken. Having been invited to visit the work in progress, D. L and C. S. were shown a series of funerary steles once erected in the old Chinatown cemetery, and later reused by the villagers as footbridges in the rice fields. Thus began their interest in old Chinese epitaphs and cemeteries in relation to social history (Vol. 9). This interest continued to develop in the years that followed; especially in Banten, where further excavation campaigns carried out within the framework of Indonesian-French cooperation in 1990, 1991 and 1992 made it possible to uncover another Chinese cemetery dating back to the last decades of the $17^{\text {th }}$ century, as well as scattered tombstones from the same period (Vol. 39, 50), but also elsewhere (Vol. 12, 41, 53, 62, 66, 72, 92).

In the early 2000s, having worked on the history of Srivijaya and China based on Chinese sources (Vol. 63), C. S.'s attention was drawn to the fortuitous and little exploited discovery (1987) on the site of Muara Jambi (East Sumatra) of a military bronze gong bearing an inscription in Chinese from the Southern Song period (1231), that raised various questions, ranging from the beginnings of the spread of the gong in Insulindia, to the smuggling of bronze artifacts, and to an possible migration of Song military refugees to Sumatra in connection with the Mongol invasion and occupation of China. This led her to revisit Jambi in 2003, and to explore Chinese archaeological surveys on various fortuitous discoveries of Song dynasty gongs (Vol. 66, 76). ${ }^{15}$

In connection with the development of a research program on epigraphic material on the history of religions in Fujian province, initiated by Zheng Zhenman 鄭振滿 and Kenneth Dean in 1987, and the publication of two corpora of inscriptions in the following years, C. S. even extended her

14. Oei Hui Lan, a daughter of the magnate Oei Tiong Ham 黃仲涵 (Semarang 1866-Singapore 1924) also published her memoirs in English: Madame Wellington Koo, with Isabella Taves, No Feast Lasts Forever, New York, Quadrangle /The New York Times Book Co., 1975.

15. See also C. S., « La diffusion du gong en Insulinde vue essentiellement à travers diverses épaves orientales (période Song-Ming) », Mirabilia Asiatica, Produtos raros no comércio marítimo. Produits rares dans le commerce maritime. Seltene Waren im Seehandel, Vol. 2, Jorge M. dos Santos Alves, Claude Guillot \& Roderich Ptak éds., Wiesbaden, Harrassowitz, Lisboa, Fundação Oriente, 2005, p. 89-116. 
epigraphic research to the Quanzhou region (Vol. 73). This new research, in order to better appraise the cultural links between Fujian and Java during the early Qing times.

From the early 1990s onwards, the condition of Indonesians of Chinese origin improved somewhat, and it became possible to undertake field work and to study the history of former large Peranakan families, such as the Hans 韓 of East Java (Vol. 41, 62, 68), and, slightly later in the 2000s, of particular minorities such as the Chinese of Surabaya (Vol. 53), the Hainanese in Bali (Vol. 60), and even specific professions such as tombstone makers (Vol. 72), and practitioners of traditional Chinese medicine and pharmacy (Vol. 74). Such fieldwork implied establishing relationships based on trust with the people to be studied, and in this respect Myra Sidharta, with whom C. S. has collaborated extensively over the years, played a key role, as did the Silas family in Surabaya, the late Tan Ting Sek 陳程錫, and the late Mouhd. Mas Oud Kasim in Makassar.

\section{Development of Peranakan Chinese Literatures}

The development over time of local born Chinese or Peranakan communities in Insulindia gave rise to hybrid cultures. On the one hand, these Peranakan progressively felt comfortable in using Malay (Vol. 20), Javanese (Vol. 34), Sundanese (Vol. 34), Makassarese (Vol. 26) and other Insulindian languages, depending upon their place of residence, but on the other, they also wanted to maintain certain elements of their ancestral culture. This explains why they enjoyed reading adaptations of Chinese traditional novels so much, hence a considerable movement of translations that extended at least from the three last decades of the 19th century to the 1960s. An advertisement in the form of a syair or poem (1886) composed by a merchant in Semarang, informing his readers that he had some forty Malay translations in book form for sale in his bookshop, gives a good idea of the importance of this movement in Java only (Vol. 8). A comparison with the Malay Peninsula shows that a similar movement occurred there, but on a smaller scale (Vol. 14). Similar translation activities took place in Javanese and in Makassarese, but the renditions have generally remained in manuscript form (Vol. 26 and 34). The apex of this movement in Java was reached with the two complete and simultaneous translations (19101912) of the historical novel of the "Three Kingdoms," Sanguo yanyi 三國 演義, one of which was published as a serial in the newspaper Sin Po 新報, which created special links between the novel, the press, and the emergence of the concept of nation (Vol. 97; for a comparison with the Philippines, see Vol. 32).

At the same time, these Peranakan authors developed a taste for writing syair. They made abundant use of this literary genre as a means of entertainment (Vol. 48), but also to recount political and other events, such as the first visit 
to Java by Siamese king Chulalongkorn in 1871 (Vol. 22), the stopover of an Imperial Chinese squadron in Batavia in 1907 (Vol. 33), and even more significantly, to express their social demands, as in the poem by Nona Tan Tjeng Nio (1897), ${ }^{16}$ written by a girl to warn young well-to-do Chinese girls against the dangers of getting married to unscrupulous men who do not hesitate to simulate love with the only goal of taking away their wealth (Vol. 28); and also to assert political demands, as in the poem commemorating the founding of the Chinese Association of Batavia in 1900 that aimed to defend the rights of the Chinese in the Dutch Indies and to develop modern education (Vol. 2).

It was also during the last two decades of the 19th century that a Peranakan author and journalist, Lie Kim Hok (1859-1912), who was strongly influenced by European literature, conceived the first modern Malay novel (1886-1887), which conveyed altogether nationalist ideas, narratives of rocambolesque ${ }^{17}$ or incredible adventures, progressive ideas about the need for founding Western style banks and for improving the education given to Chinese girls (Vol. 48).

This literature in Malay, and to a lesser extent in Javanese, Sundanese, and Makassarese opens up new horizons about Peranakan, who by virtue of their special status in the Malay Peninsula and the Dutch Indies had been able to take advantage of both Chinese and European cultures, which for a few decades had given them a certain lead over the local population. Worthy of note, in the Straits Settlements, where education in English was provided from the first decades of the $19^{\text {th }}$ century onwards, educated Babas, such as Lim Boon Keng 林文慶 (1859-1957), and Song Ong Siang 松旺相 (1871-1941), rapidly abandoned Malay in favour of English, and also Chinese.

In addition, the revelation, nearly fifty years ago, of a large corpus of literature, hitherto unsuspected by Westerners, and since then often named "Sino-Malay Literature," has somewhat shaken up preconceived ideas about the beginnings of "Indonesian literature" (Vol. 3). A new branch of research on Malay/Indonesian literature written by Sino-Indonesians, which until then had only been conducted by Peranakan journalists, more especially Tio Ie Soei (1890-1974) and Nio Joe Lan (1904-1973), has gradually developed. ${ }^{18}$

This rich corpus, if we consider it well, also allows us to observe how descendants of Chinese have gradually made a place for themselves within the Indonesian nation.

16. The poem was very well received and was reissued at least five times, the last one in 1921. Plate 1.

17. From "Rocambole", name of the main hero of Ponson du Terrail's novels, some of which were translated into Malay by Lie Kim Hok.

18. When writing in Dutch in the 1930s for De Indische Gids, Nio Joe Lan called this literature "de Indo-Chineesche literatuur". After World War Two when he adapted his series of articles into Indonesian, he gave his book the title of Sastra IndonesiaTionghoa (Jakarta, Gunung Agung, 1962). 


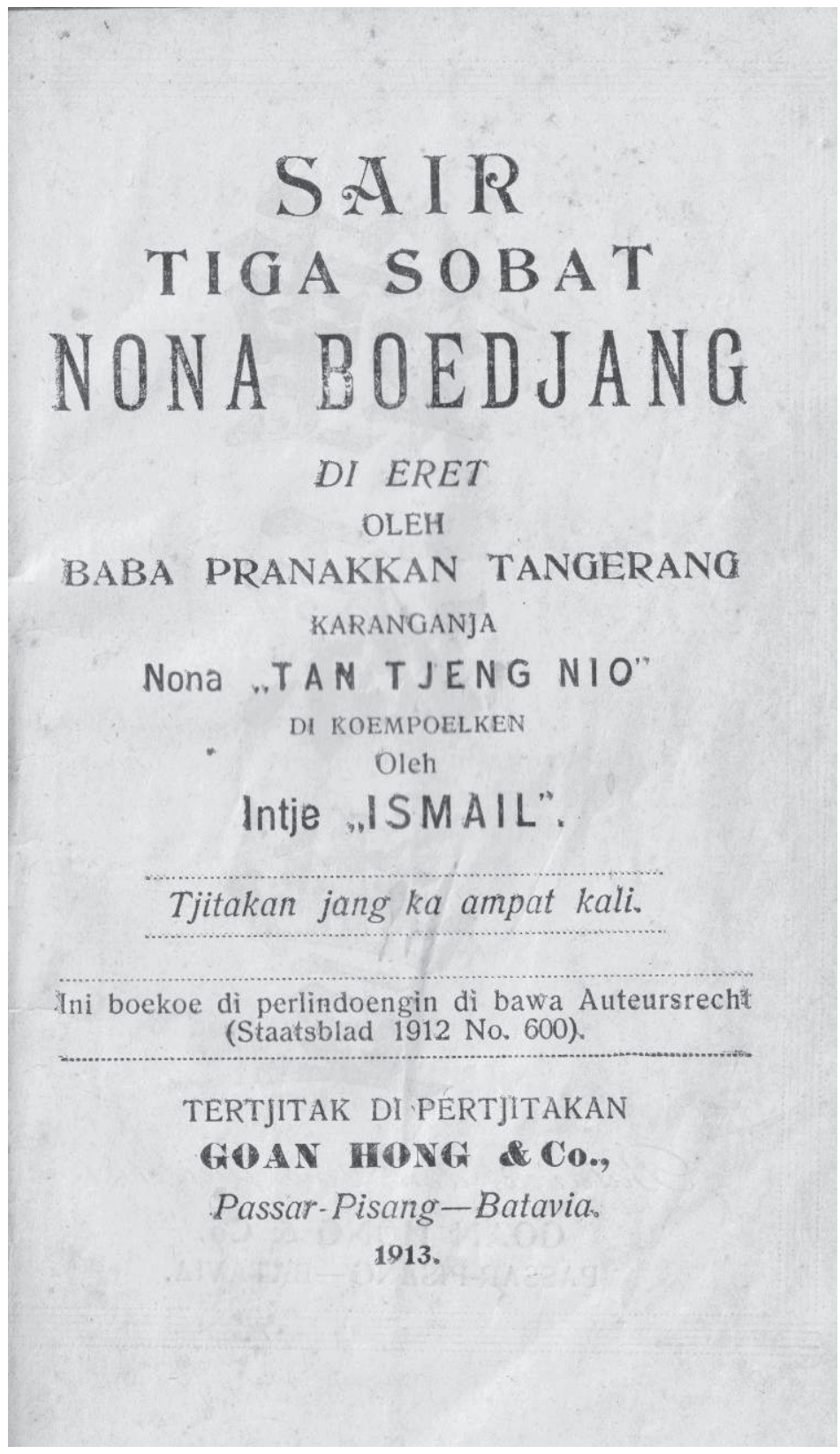

Plate 1 - Cover of Sair Tiga Sobat Nona di Eret oleh Baba Pranakan Tangerang by Tan Tjeng Nio, Ed. of 1913. 


\section{Elaboration of an Insulindian Literature in Chinese}

It is difficult to determine what was the place of local literature in Chinese in $19^{\text {th }}$-century Indonesia, because it has been poorly preserved, no doubt due to the fact that it has remained handwritten, and also because of the successive political outbreaks that have shaken the country over time. It has been better circulated in Singapore and Penang where a press in Chinese appeared in 1881 (Vol. 6) and 1895 respectively. No Hokkien poem, other than the one discovered by Schlegel (see introduction), has been found so far. Travelogues, youji 遊記, from South Seas merchants have long been ignored by sinologists, ${ }^{19}$ although as far as Singapore is concerned, the oldest newspaper in Chinese, the Lat Po 叻報 ${ }^{20}$ (founded in 1881) contributed to the development of this literary genre. Local scholars have shown that "educated" merchants knew how to combine business and culture and had developed a certain taste for excursions. Such accounts allow us to analyse the way these merchants looked at Europeans, Vietnamese and Chinese, and to better perceive their conceptions of space, their views of political order, and their economic networks. Moreover, one casts a light on the Baba diaspora in China and Japan. Two travel accounts, emanating from Tan Keong Sum 陳恭三 (Plate 2), and Li Qinghui 李清 輝, two Babas based in Singapore, and narrating trips to Saigon (1888), to China and Japan (1889) that were published in the Lat Po, and a third one in manuscript form from Tan Siu Eng 陳琇榮[瑩] (Xiamen 1833 - Batavia 1906), the assistant of the sinologist W. P. Groeneweldt (1841-1915) then member of the Council of the Indies, relating an official trip to Saigon (1890), were presented and translated in Archipel (Vol. 43, 47, 56). ${ }^{21}$

With the $20^{\text {th }}$ century and more particularly the movement of May 4, 1919, the Chinese decided to write henceforth in baihua 白話, or colloquial Chinese. This movement had repercussions in the diaspora, where a new literature, widely published in the press, spread into the big cities, particularly in the Malay Peninsula and Singapore and, to a lesser extent, in Indonesia. Here, this new literature is considered in at least four articles. Two (Vol. 28, 24) elaborate on the development of mahua wenxue 馬華文學 or Sino-Malaysian literature, ${ }^{22}$ the first of the two providing an overview for the period 1919-1941, during which it was mainly the product of male authors who were native to China and had

19. For a comparison with travelogues written by mainland China merchants, see Vol. 52.

20. The name of this journal derives from the Malay term selat which means "straits", and was used by Hokkien and Cantonese to refer to Singapore.

21. Against one travelogue in Malay recounting a trip to Paris in 1889 (Vol. 54).

22. After the separation of Singapore from Malaysia in 1965, the name given to this literature was changed to xin-ma huawen wenxue 新、馬華文文學 or “Literature in Chinese from Singapore and Malaysia." 


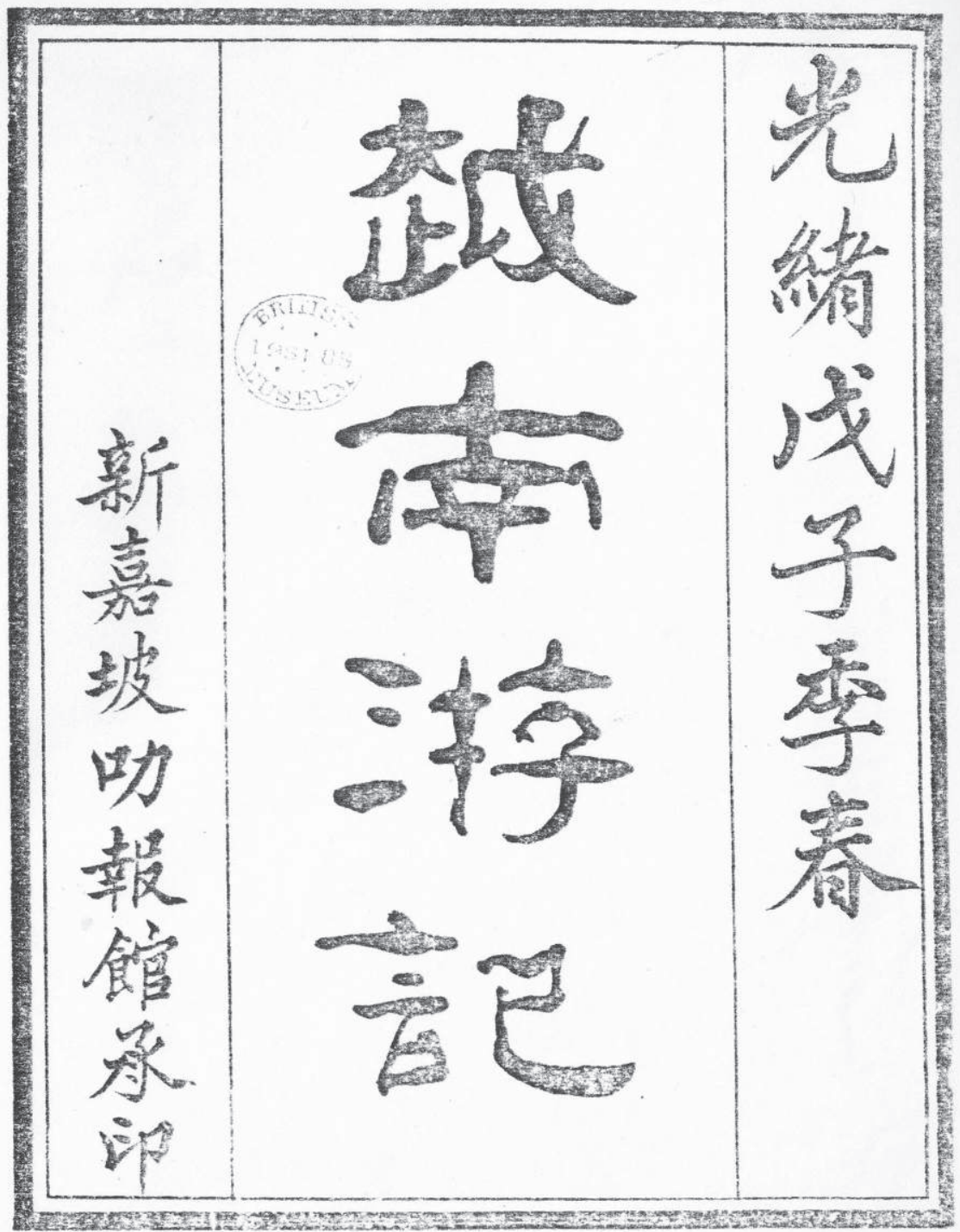

Plate 2 - Cover of Yuenan youji (Vietnam Travelogue), Xinjiapo, Libaoguan chengyin, Guangxu wuzi (1888). 
migrated in order to escape political difficulties. The second emphasizes the part played by women writers in this movement. For the same period, only two women writers have emerged: the poetess Yingzi 瑩姿, and Madam L.S. who from 1927 to 1929 regularly contributed to a newspaper supplement called Huangdao 荒島 “Deserted Island”, supplement to Xin guomin ribao 新國民日報 “New People's Daily." She showed much concern about women's social status, and asserted that "it was due to the biased social system that woman had become mere dependent on men." (Vol. 24, p. 208). Since 1965, more and more women have joined in literary writings. In their works, they complain about the hardships and sufferings that the family and the community have imposed upon them. They have also extended their concern to the affairs of other ethnic groups.

The third article (Vol. 23) deals with the importance of autobiographical narratives for the history of the Chinese diaspora in Southeast Asia, as seen through the tribulations of a Chinese journalist in the South Seas (1917-1971). The fourth investigates the political vision of a selection of post-World War II Insulindian authors of their own society, by focusing on the theme of taoke 頭 家 “businessmen" and coolies (Vol. 26), and the values that place individuals in the social hierarchy.

In short, these studies on literary production in both ancient and modern Chinese, largely ignored until now, except by local and Mainland Chinese researchers, give a first idea of what can be drawn from it for a better understanding of the Insulindian Chinese communities, as well as their cultural links with the motherland.

\section{Role of Women in the Making of Sino-Insulindian Communities}

If the study of the various literary productions has been in many ways a revelation of the social and political condition of the Insulindian Chinese, that of the very special place of women within their communities, both indigenous, and of Chinese origin, is no less so.

Formerly, when merchants arrived from China, they acted like those of other nations, who came to trade like them, and bought a woman whom they resold, if by chance they returned to their country. However, the judicial archives of the Council of the Chinese in Batavia from the late $18^{\text {th }}$ century show that such local female slaves (mainly from Bali and also from South Celebes) could be promoted to the position of concubine (qie 妾), which entailed a relative liberation from their bondage and made them eligible to receive part of the inheritance. Another possibility was to become a "Chinese lady." In order to cross this boundary, a native woman had to be adopted by a Chinese gentleman and receive a Chinese surname. Then she was eligible for formal marriage according to the Chinese rites. (Vol. 72). ${ }^{23}$

23. See also Yuan Bingling, "Chinese Women in Jakarta During the Colonial Period", Asian culture/亚洲文化, 26, June 2002, p. 53-57. 


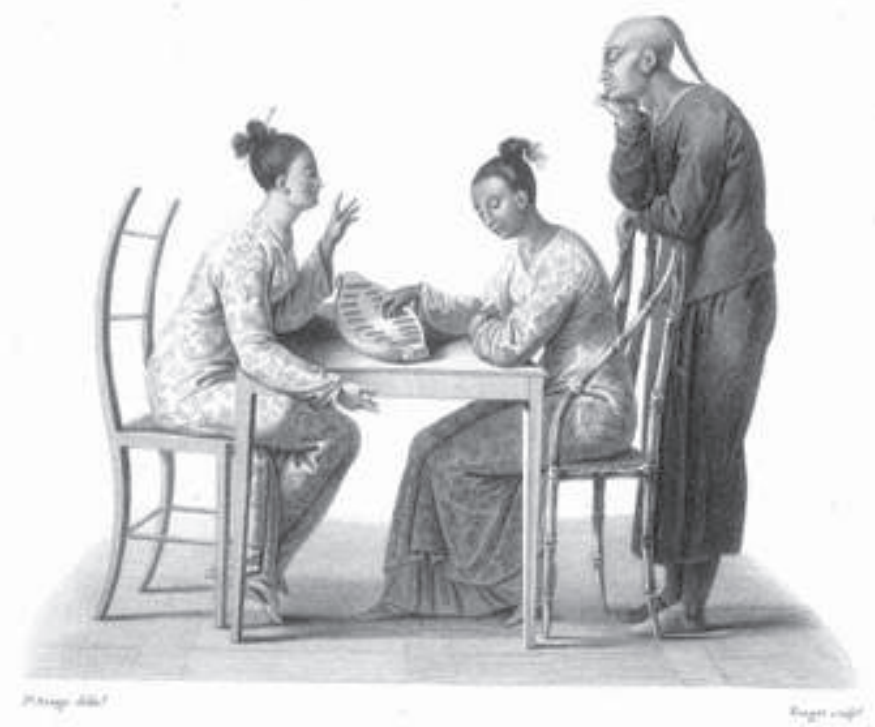

Plate 3 - Chinese Girls Playing Congkak in Kupang, Timor, reproduced from Freycinet, Voyage autour du Monde..., 1824-1844.

Some of these women seem to have been held in high esteem. For example, upon the death of Siqua (Yan Erguan 顏二官), the head of the Chinese community of Batavia in 1666, he was succeeded by his widow, a Balinese, who held the office of "captain" until 1678, when a man was elected to replace her, following protests from some Chinese people. Some women went so far as to master certain elements of Chinese medicine. Two of them living in the first decades of the 18th century remained famous for having cared for the families of two governors-general for many years (Vol. 16).

It remains that it is difficult to perceive how these women of local origin became sinicised. ${ }^{24}$ An interesting fact is that Peranakan wives were very concerned about introducing their names and those of their parents into Chinesestyle genealogies. Some even went much further by introducing their family's ancestral tablets into the ancestral temples of their husband's families, such as in Makassar. Eighteenth-century Chinese sources praise some "Chinese" ladies

24. See Plate 3, reproduced from Louis-Claude de Saulces de Freycinet. Voyage autour du Monde fait par ordre du Roi, sur les corvettes de S.M. l'Uranie et la Physicienne, pendant les années 1817, 1818, 1819 et 1820... publié par M. Louis de Freycinet, Capitaine de Vaisseau, commandant de l'expédition... Paris, Pillet aîné, 1824-1844. 7 tomes de texte en 9 vol. in $-4^{\circ}$ et 4 vol. d'atlas gr. in. Folio, Plate 25. 
of Batavia for their great virtue, which shows that the conception of the ideal Chinese woman had made its way beyond the seas. However, there were limits to this sinicisation. For instance, the custom of foot-binding, which was very widespread in China never spread to the South Seas. It is the hybrid culture of these women that has given the Peranakan communities their special character (Vol. 16). The particular status of Sino-Insulindian women is also reflected after their death on their epitaphs, by an ultimate construction that was aimed at integrating them into a symbolic Chinese world, and giving them posthumous names that reflected the status of their husbands, as in China (Vol. 72).

During the second half of the $19^{\text {th }}$ century and even more during the early $20^{\text {th }}$ century, Peranakan women in the Dutch Indies became more and more westernized and developed a taste for writing fiction and contributing articles in Malay in the press, and even claimed a certain emancipation (Vol. 28, 42, 49, and Plate 4).

It is more difficult to perceive the role of women of Chinese origin in these communities. It is towards the end of the $14^{\text {th }}$ century or the beginning of the $15^{\text {th }}$ that the emigration of Chinese women to Insulindia may be traced. Several adventurers from Guangdong accompanied by their families moved to Palembang (South Sumatra) to stop ships and rob them of their valuables. In this society of pirates and outlaws, women had the same rights as men. but the fact was not well considered and Chinese texts are discreet on this subject. It seems that there have always been some emigrants to take their wives with them. But it was not until the $19^{\text {th }}$ and $20^{\text {th }}$ centuries that a large-scale trade in women for prostitution to the South Seas developed. As far as voluntary female migrants are concerned, for the second half of the $19^{\text {th }}$ century, these were wives going to join their husbands. In the female emigration of the $20^{\text {th }}$ century, three particular new social groups appeared: teachers, Buddhist nuns, and maids (Vol. 16, 19, 23).

The massive arrival of Chinese women, from the last decades of the $19^{\text {th }}$ century up to 1941 , contributed to changing the nature of Insulindian Chinese communities by resinicising for several decades a way of life that had borrowed heavily from the host countries, and consequently by cutting the new migrants off from the population of their host countries.

\section{Technical Knowledge, Trade and Transfers}

It is particularly difficult to study the economic role of Chinese migrants from a historical point of view, due to the rapid evolution of profit patterns and political instability over time. Here we are going to evoke successively sugarcane processing in West Java, ceramic manufacturing in Sarawak and West Kalimantan, and birds' nest exploitation in Indonesia.

\section{Sugarcane Processing and Trade in the Sultanate of Banten}

The archaeological excavations carried out in 1988 in cooperation with the Archaeological Service of the Republic of Indonesia, and EFEO, together 


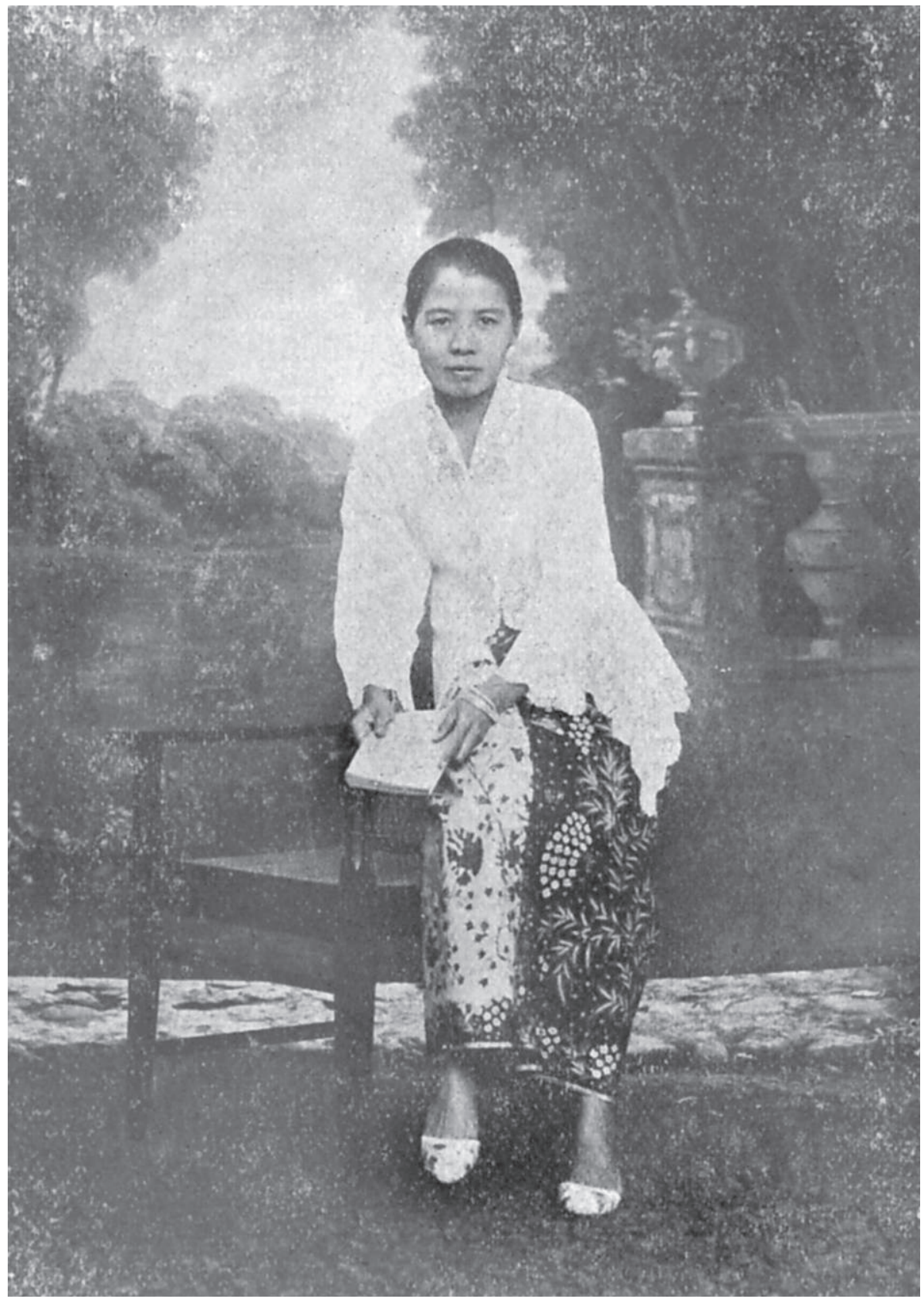

Plate 4 - Portrait of Journalist and Writer Siem Piet Nio, pseud. Hong Le Hoa (b. in 1907). Private Collection. 
with information from $17^{\text {th }}$-century European sources, have made it possible to identify to the south of the old city of Banten or Banten Lama, in the village of Kelapadua, formerly linked to the coast by a river, the remains of a quarter which was inhabited by Chinese farmers. From the 1630s until the victory of the VOC over the Sultanate in 1682, these farmers cultivated sugarcane quite extensively, and manufactured white sugar and arak in order to supply British buyers, with whom they signed contracts. According to the contracts signed in 1638 with six producers, the British intended to buy more than 17 tons of white sugar (Vol. 39). After 1682, the Chinese planters moved to the coast in the areas of Tanjung Kait and Sumurangsana, to the west of Ci Sasanada River, where the Dutch became their exclusive buyers. The few epitaphs found in Kelapadua and datable from the second half of the $17^{\text {th }}$ century (1660s-1670s) show that the deceased originated from Zhangzhou 漳州 prefecture (South Fujian), a region known for its sugarcane plantations and sugar processing since the Song times (960-1278).

By the end of the $17^{\text {th }}$ century, these sugar factories had largely exhausted the forests of the surrounding area, and slightly later those of the Batavia region, and during the second half of the $18^{\text {th }}$ century, little by little sugar refineries moved eastwards to Central Java and to East Java. This is how two great Chinese families of Surabaya, the Hans 韓 and the Tjoas 蔡, took part in the modernization of the sugar industry and sugar's peak expansion until the effects of the 1920s and of the great crisis of the 1930s were felt in Java, which resulted in a period of retrenchment and partial recovery prior to World War II (Vol. 53).

\section{Migrant Chinese Ceramic Manufacturing}

While Chinese export ceramics have been the subject of a fairly large number of studies, the migration of Chinese potters to Insulindia and the construction in situ of dragon kilns, longyao 龍窯 (so called because of their elongated shape spreading out on a slope) that were modeled on those in use in South China since remote times, has attracted little research.

However, at the very beginning of the 1980 s, three researchers investigated some of the ceramic factories still in operation in Singkawang (West Kalimantan), Sarawak, and Sabah (Vol. 26). The first two scholars explored three manufactures located in the village of Padang Pasir $(6 \mathrm{~km}$ to the south of Singkawang), focusing on raw materials and tools, the kiln, and the distinct stages of the manufacturing process. The third scholar concentrated her research on the manufactures in the areas of Kuching, Sibu, and Miri (Sarawak), and Kota Kinabalu (Sabah). She was interested in the origin of these potters who all came from the Chaozhou 潮州 region (Guangdong) and were related to each other. The founder of the oldest and largest manufacture in Sarawak settled in Tanah Putih (Kuching) in 1910, a little later than in Singkawang (Vol. 66). Their production was diversified, reaching both urban consumers, and the Dayak living in longhouses in the interior of the country, 
for whom they made large jars (tempayan) in order to replace those formerly imported from China. ${ }^{25}$

This traditional technique appears all the more interesting as the use of dragon-kilns seems to have declined in China, in favor of kilns of different models. Nowadays, those still in use in Insulindia are becoming extremely rare too, so that an ultimate survey would be greatly welcome. ${ }^{26}$ A question that would deserve to be raised is how the potters prospected to locate the indispensable clay? Did they send out prospectors to identify suitable locations, or did they rely on information given by the local population? True enough, some place names indicate the presence of clay, such as Sungai Liat, literally "clay river," in Bangka, where Chinese potters actually came to settle, apparently at the beginning of the 20th century. When we visited that place in the 1990s, they were still making cups to collect latex in rubber plantations, as well as ordinary tableware.

\section{Exploitation of Edible Birds' Nests, A Long-term Business}

The importance given to swiftlet's nests in Chinese dietetics over the centuries has led to a long-lasting trade with the South Sea countries which continues to this day, and to which could be compared those of shark fins and of trepang or bêche-de-mer.

The term yanwo 燕窩 or “swiflet's nest” appears apparently for the first time in a dietary compendium Yinshi xu zhi 飲食須知 or “Essentiel Knowledge for Eating and Drinking" (1368), which stresses prevention of illness rather than treatment. It seems that the nests were first collected in South China and eaten locally by commoners before being imported from the South Seas, especially from Champa and Insulindia during the $15^{\text {th }}$ and early $16^{\text {th }}$ centuries. In the 1590 s, this taste for birds' nests was extensively shared by the elite and has spread to northern provinces. The booming consumption of this delicacy during the following centuries resulted in a huge quest for swiflet's caves all over the archipelago, and the control of the birds' nest trade, at first by local rulers, subsequently by the Dutch and the Indonesian authorities.

25. Further studies have revealed that all the Chinese potters who settled in continental Malaysia and in Singapore were Teochews, originating from the same potters' village in Guangdong province (Fengxi or Pangkhoi 枫溪) in the Chaozhou 潮州 region. The first ones settled in Kuala Lumpur in 1905, followed by others in Ipoh, Malacca and Kluang. Their production was often linked to tin mines because of the suitable clay and aimed at the domestic needs of Chinese workers as well as the fabrication of latex cups for the rubber estates. See M-F Dupoizat, Recherches sur les jarres en Asie du Sud-Est, Thèse de doctorat, EHESS, Paris, 1988.

26. In the post-World War II era, Singapore had over 20 dragon kilns in Jurong, Pulau Tekong, Pulau Ubin and Serangoon. But in the 1970s, the number of dragon kilns dwindled to about 10, and they were all located in Jurong. http://navalants.blogspot. com/2017/12/dragon-kiln.html. Retrieved on 5/10/2020. 
The big novelty in the birds' nest exploitation was a progressive shift from collecting cave and cliff nests to the practice of swiftlet farming. It is probably the fact that swiftlets came to live of their own accord in old European-style houses in Java, forcing their occupants to give way to them, which was at the origin of the breeding of burung walet in urban areas. The production of house nests (sarang rumah) has developed considerably since the 1980s, giving rise to the production of a new type of knowledge aimed at taming and raising swiftlets in centres set up for this purpose (sentra walet).

In addition, some contractors have specialized in the construction of such buildings, ranging from blockhouse-style buildings to urban dwellings that, from the outside, are indistinguishable from the residences of the elite. Sometimes, these are sold "turnkey" and even with their population of swiftlets. Research on these birds continues to develop and several experts travel to spread their knowledge throughout Indonesia, but also abroad, notably in Malaysia, Brunei, Thailand, and Vietnam. Several books and VCDs in Indonesian are also available in Chinese, English and Vietnamese. The first centre for swiftlet research, services and equipment sales, the Eka Walet Center/ Pusat Informasi dan Sarana Budidaya Walet, was founded in Semarang in 1989, by the veterinarian E. Nugroho with the help of other practitioners.

At the time this research was published in 2005 (Vol. 76), Indonesia was the leading producer and exporter of swiftlet's nests. For years, the sale of birds' nests was largely unregulated, but in 2011 Indonesia's bird's nest industry experienced serious backlash when China imposed a ban on Indonesian exporters due to a high concentration of nitrate, lead and arsenic found in some products. As per October 2018, only 21 out of more than 100 exporters in Indonesia passed the long and tedious certification process according to new regulations, that allow them to sell their production legally, the remaining being illicitly sold in black markets at cheaper prices via a third party, in countries like Vietnam. ${ }^{27}$

\section{Circulation of Traditional Chinese Medicine and Pharmacy}

The practice of traditional Chinese medicine is also a long-term undertaking on which there is a very rich bibliography in Chinese, but also in the European languages. It has been questioned both scientifically and politically following the introduction of Western medicine to China in the late 19th century. It has been able to survive and even redeploy nationally and internationally because of its intrinsic values, the resilience of the practitioners, but also because of particular political circumstances.

27. China's birds' nest crackdown leaves Indonesia struggling to feather its... http://www.scmp.com/week-asia/business/article/2152955/chinas-birds-nestcrackdown-leaves-indonesia-struggling-feather. Retrieved on 13/10.2020. 
The trade in plants and other medicinal products in Asia, particularly between China and the South East Asian countries, dates back to the dawn of time. It seems that Chinese doctors started travelling to South Sea countries at a very early stage. The story goes that when the prefect of Giao Chi 交趾 (present North Vietnam), Shi Xie 士䃞, fell seriously ill in $226 \mathrm{CE}$, he was healed by the Buddhist monk Dong Feng 董奉 who was then famous for his medical knowledge, by a single pill. For subsequent periods, the chronicles have kept the memory of the most famous physicians who cared for various sovereigns. When Admiral Zheng He 鄭和 (1371-1433) undertook his great maritime expeditions at the beginning of the 15th century, he hired 180 doctors whose mission was to monitor the health conditions of the crew, but also to study the various medicines of the countries visited.

During the Ming Dynasty and notably after the fall of the dynasty more physicians and pharmacists went abroad. European sources mention the presence of Chinese pharmacists in Manila from the end of the 16th century, and Chinese doctors in the service of the kings of Siam, but also of the Vereenigde Oostindische Compagnie (VOC) or United East India Company employees in Batavia, at the beginning of the following century.

The truth is that very little is known about the early history of Chinese medicine in Insulindia, which has not been studied by European physicians. The information in our possession comes from travelers and employees of the VOC. We know for instance that in 1635, the Christian Chinese physician Master Isaac was appointed physician of the Company in Batavia with an enormous emolument. In 1640, the Chinese of that city obtained the permission to collect money in order to erect a "Chinese Hospital," called in Chinese Yangji yuan 養 濟院 or "Hospice for the Poor," that was completed in 1646. It was run by a committee including Dutch and Chinese administrators among whom Master Isaac. But nothing is known regarding the nationality of the physicians and the apothecary attached to that institution. Dutch sources also allude to the arak distiller Tjoebitia 周美爹, who was also a prominent doctor. He used to treat Governor-General van Horn (in office 1704-1709), who was a great sinophile. Another respected physician was the wife of a certain lieutenant who during thirty years used to treat the family of Governor-General Matheus de Haan (in office 1725-1729). ${ }^{28}$ From the second half of the $18^{\text {th }}$ century onwards the Europeans apparently became less attracted to Chinese medicine, because we hardly find any reference to famous physicians in Dutch sources.

The Chinese epigraphic corpus of Indonesia allows us to trace the names of some apothecaries, where doctors generally had their practices. In the last decades of the $19^{\text {th }}$ century some of them published announcements in the press.

28. In Ming/Qing China women doctors were very common. 
From the late 1890 s to the beginning of the $20^{\text {th }}$ century, with the rise of modern medicine or xiyi 西醫, traditional medicine, zhongyi 中醫, was sharply attacked in China proper. In 1929, the newly established Ministry of Public Health took a resolution aimed at abolishing old medicine. As a result, traditional Chinese practitioners at home and abroad organized themselves to deal with the emergency. The traditional doctors were finally successful: in 1935, a resolution demanding "equal treatment for Chinese and Western medicine" was passed. In fact, it was World War II that brought the rehabilitation of Traditional Chinese medicine (TCM), due to the lack of western-trained doctors and western drugs outside the big cities. Schools of Chinese medicine were established in China, Hong Kong and Singapore in the 1950s. Exchanges between China and Indonesia occurred in the early 1960s. In 1962 nine Chinese doctors were officially sent to Jakarta to treat Sukarno. But with the ascent of Suharto, practitioners of TCM found themselves in a critical period for their profession, while the importation of ready-made Chinese medicines was prohibited.

The practitioners of TCM and acupuncture, who in 1975 created an organisation supported by Sino-Indonesian medicine merchants, succeeded a few years later in establishing schools for traditional medicine, first in Jakarta and then in other cities. Thus, TCM was gaining a foothold in Indonesia and international symposia were organised throughout ASEAN. The boom in TCM started in 1985 when business relations with PRC were normalized. With the progressive liberalization of the economy during the presidency of Megawati Sukarnoputri, the import of Chinese medicine entered into a new phase, while PRC doctors in TCM were permitted to work in Indonesia provided there should be a transfer of technology. At the time this research was completed (Vol. 74), several modern traditional health centers had been founded in Jakarta and a few other big cities, all operating with PRC Chinese practitioners working with local interpreters. Compared to the local TCM dispensaries, which cater to all classes, but particularly to those with little money, these new centres are aimed at a rather well-to-do clientele.

\section{The Place of the Dead in the World of the Living}

The leaders of Chinese communities abroad had the duty to look after the living as well as the dead. They had to help the former in case of need and ensure that the latter rested in peace in pleasant and soothing places. Despite the incessant expenditure over time, both individually and collectively, by the Chinese of Insulindia to conserve and secure their graveyards, the latter have never been really protected from destruction. As early as 1668 , the community of Batavia lodged a complaint against a group of Ambonese who resided next to their cemetery and had desecrated some four hundred graves. This struggle for space between the living and the dead in urban context has grown steadily over the centuries. Since the $20^{\text {th }}$ century, municipalities have planned the 
destruction of urban cemeteries, as has occurred in certain European countries during the $19^{\text {th }}$ century.

In the Chinese world, where dialogue between the living and the dead is extremely important and constantly renewed, these measures cause serious mental suffering, all the more so as the former are attached to their ancestral values, without the slightest possibility of putting them into perspective. If the humblest ones accept willingly or unwillingly giving up burials for cremation, as soon as they move up in society, people make enormous sacrifices to offer their ancestors a place to rest in peace. During the second part of the $20^{\text {th }}$ century, Chinese businessmen were quick to realize that they could make huge profits by creating luxurious memorial parks on the outskirts of major cities (Vol. 92). In doing so, some promoters have intervened culturally by projecting in these memorial parks various cultural elements aimed at visualizing the greatness of Chinese culture, notably in Malaysia. It should be noted that Singapore does not follow this new trend, as the authorities have in principle prohibited the burial of the deceased, both on the territory of the republic and abroad.

Memorial parks as well as cemeteries must conform to the land-use plan or zoning ordinance site, and must be located on the periphery of the town or in sparsely inhabited areas of the locality having jurisdiction over the project. These new cemeteries, well maintained and boasting a pleasant atmosphere that is more or less Chinese, progressively have attracted families, even among those whose deceased are buried in old cemeteries, and who not long ago were struggling against their destruction. After hesitating more or less, they decide to discreetly transfer the remains of their ancestors to these memorial parks. Thus, they contribute to the destruction of the traces of their own history, which previously they wanted to preserve...

This collective research highlights the still highly significant place of the dead among people of Chinese origin, and the intellectual suffering caused by urban planning on the run. It also shows how the world of local entrepreneurs has seized death as a new source of profit. In the case of Malaysia, the funeral entrepreneurs had the idea of using new cemeteries as places in which to revive Chinese culture by visualising the past through a gallery of famous stelae, and by reproducing certain cultural landscapes in miniature form. In the Philippines, as in Indonesia, the tendency is rather to reunite the deceased beyond ethnic diversity, which is a way for the living to affirm their belonging to their host country. This is how politics makes its mark, even after death.

At the time this collective essay was published (Vol. 92), this model of new cemeteries had found its way into mainland China and into Muslim circles in Malaysia as well as in Indonesia.

\section{Sino-Indonesian Architecture and the Notion of Cultural Heritage}

It is to a specialist in the evaluation of hydrocarbon wells that we owe the merit of having drawn attention to the sinicised architecture of the Pasisir 
by a cahier d'images or "Collected Images" (Vol. 51), at a time when any Chinese contribution to Indonesian culture was strongly denied, and several years before the concept of "cultural heritage" or warisan budaya made its way among Sino Indonesians. ${ }^{29}$ The sailboats coming from Madura, Buton and Celebes stopped loading in the small ports of Gresik, Tuban, Lasem, and Rembang, in favour of the trucks now draining the products from the hinterland to the big cargo ships of Surabaya, and these small intermediate ports and their sinicised architecture gradually died out. This is precisely the time when P. Piollet built up his photographic corpus, which he since donated to Petra Christian University of Surabaya.

In Indonesia, unlike Malaysia, very few Peranakan families of long standing have managed to preserve and maintain the magnificent half Chinese-half European houses built by their ancestors during the $19^{\text {th }}$ century. The three first heritage museums created between 2003 and 2011, one in Java, and two in Sumatra, were in fact established in houses that formerly belonged to Chinese newcomers. ${ }^{30}$ However, apart from private initiatives aimed at safeguarding certain buildings, so far little has been done at the national level to safeguard endangered Sino-Indonesian monuments.

\section{Conclusion}

The study of Sino-Insulindians can be made in relation to the country of their ancestors, more precisely in relation to the successive policies of China and those of Insulindian countries with regard to the citizenship of the Chinese diaspora. For a time, the emphasis has been placed on the political problems these policies generated at the international level, especially since the end of World War II, and consequently the necessity for these ethnic Chinese living abroad to make a choice in terms of nationality, with all the implications that this entailed.

Here in Archipel, apart from a few articles that deal with national and regional identity, as well as patriotism (Vol. 14, 32, 39, 61, 84), the tendency has been towards the investigation of economic, social, cultural, and religious facts, as seen from within Insulindia. Although not immune to political circumstances, these facts spread over a rather long period of time, and in many ways affect various constituents of the host society, and to a lesser extent of mainland China.

29. The concept of heritage first appeared in Malaysia with the foundation in 1984 of the Malacca Chinese Hill Heritage Park, in Chinese Wenhua yichan gongyuan 文 化遺產公園, also called “Historic Place”, [Lishi] guji gongyuan [歷史]古跡公園, at a time when Bukit Cina, the oldest Chinese cemetery, was endangered by urban expansion and property developers. See C. Salmon, "Sino-Insulindian Private History Museums, Cultural Heritage Places, and the (Re)construction of the Past," Asian Culture 42 December 2018, p. 2-4.

30. Op. cit., p. 6-8. 
Some studies aim more specifically at studying the different processes of integration at the socio-economic, cultural and religious levels. At the socioeconomic level, integration efforts range from those of the newly arrived migrant who laboriously negotiated his services on the street where the different social classes rub shoulders, to those of the big businessmen who dealt with the men in power, and ended up making themselves indispensable. At the cultural level, the processes of adaptation are endless, ranging from an attempt to master the culture and language of the other, while striving to maintain all or part of one's own culture, to personal creations aimed at "translating" his or her own culture into the local ones, but also at participating in the local cultures through his or her own writings. The supreme degree of integration consists in going so far as to adopt the religion of the other, either individually, and eventually more or less collectively in relation to dramatic political events, such as the massacre of the Chinese in Batavia in 1740, and the events of 1965 in Indonesia.

Studying the Chinese component of Insulindian societies is also a way of highlighting their cultural diversity and richness which are in perpetual motion. In this respect, it could be regretted that the journal Archipel has not served as a platform for similar studies of the Arabic component. ${ }^{31}$

Last but not least, with the arrival of new Chinese migrants since the end of the 20th century, but especially in the early $21^{\text {st }}$ century, new problems have arisen in terms of their impact on existing Chinese communities and on the host countries as a whole, which should also be addressed in this review. ${ }^{32}$

\section{References in Chronological Order}

Archipel 2, 1971, C. Lombard-Salmon, "Le Sjair de 1"“Association chinoise" de Batavia (1905) », p. 55-100.

Archipel 3, 1972, C. L-S, « Société peranakan et utopie : deux romans sino-malais (19341939)», p. 169-195.

Archipel 6, 1974, J.-R. Bure, « La presse chinoise quotidienne de Singapour », p. 185-204.

Archipel 8, 1974, C. L-S, « Aux origines de la littérature sino-malaise : Un sjair publicitaire de $1886 »$, p. 155-186.

—, C. L-S., « Récentes études épigraphiques chinoises en Asie du Sud-est », p. 213-223.

Archipel 9, 1975, C. et D. Lombard-Salmon, «À propos de quelques stèles chinoises récemment retrouvées à Banten (Java ouest)», p. 99-127.

Archipel 11, 1976, C. L-S., « Une morale en images : les peintures murales du Xie-tian-gong de Bandung », p. 167-176.

—, C. L-S., « Les Chinois d'Asie du Sud-est en quête de leur propre histoire », p. 249-254.

31. Except for one article by Yusof A. Talib in Vol. 7, 1974.

32. See Leo Suryadinata, "New Chinese Migrants in Indonesia: An Emerging Community that Faces New Challenges," ISEAS Perspective, June 2020, N 61, p. 1-10. 
Archipel 12, 1976, C. L-S., " À propos de quelques tombes chinoises des XVII" et XVIII" siècles », p. 207-218.

Archipel 14, 1977, E. Edwards Mckinnon, "Research at Kota Cina, a Sung-Yüan Period Trading Site in East Sumatra", p. 19-32.

—, D. Lombard, « Les maître de silat d'origine chinoise, contribution à l'histoire des arts martiaux dans l'Archipel », p. 33-41.

-, Leo Suryadinata, "The Search for National Identity of an Indonesian Chinese: A Political Biography of Liem Koen Hian", p. 43-70.

—, C. L-S., « Tio Ie Soei, journaliste et homme de lettres de Jakarta (1890-1974)», p. 71-77.

—, C. L-S., « La littérature en malais romanisé des Chinois de Malaisie : première enquête », p. 79-109.

Archipel 16, 1978, C. L-S., " Le rôle des femmes dans l'émigration chinoise », p. 161-174.

Archipel 17, 1979, C. Salmon, «Lawah-lawah Merah ou «l'Araignée rouge" : un «roman sinomalais» qui s'avère être la traduction d'un roman français », p. 63-69.

Archipel 18, 1979, C. S. et D. L., «Un vaisseau du XIII ${ }^{\mathrm{e}}$ s. retrouvé avec sa cargaison dans la baie de «Zaitun », p. 57-67.

—, Léonard Blussé, "Chinese Trade to Batavia during the Days of the V.O.C.”, p. 195-213.

Archipel 19, 1980, John B. Kwee, "Kwee Tek Hoay: A Productive Chinese Writer of Java (1880-1952)", p. 81-92.

—, C. S., «Être femme à Singapour », p. 161-168.

—, Ho Khai-leong, "Modern Chinese Poetry in Malaysia”, p. 199-206.

—, K.S. Maniam, « La tradition poétique de langue anglaise en Malaysia et à Singapour» (trad. de B. Milcent), p. 207-217.

Archipel 20, 1980, C. S., « La notion de sino-malais est-elle pertinente d'un point de vue linguistique? », p. 177-186.

Archipel 22, 1981, Marie-Sybille de Vienne, «La part des Chinois dans les fermes fiscales de Batavia au XVIIème s. », p. 105-132.

-, C. S. et D. L., « Le poème en malais d'un peranakan sur la visite du Roi Chulalongkorn à Batavia en $1871 »$, p. 133-166.

Archipel 23, 1982, Brigitte de Beer-Luong, "Les tribulations d'un Chinois dans les Mers du Sud (1917-1971)», p. 109-118.

Archipel 24, 1982, C. S., « Note sur les études chinoises concernant l'Insulinde », p. 23-29.

—, Yu Wang Luen, "Women Writers of Malaysian Chinese Literature", p. 205-234.

—, Myra Sidharta, "Introduction to the Works of Queeny Chang", p. 235-245.

Archipel 26, 1983, Abu Ridho et Wahyono M., « La fabrication de la céramique à Singkawang (Kalimantan-Ouest) », p. 117-126.

—, Marie-France Dupoizat, «L'artisanat de la céramique en Malaysia orientale », p. 127-142.

Archipel 26, 1983), Gilbert Hamonic et C. S., « La vie littéraire et artistique des Chinois peranakan de Makassar (1930-1950) », p. 143-178.

-, C. S., "Taoke or Coolies ? Chinese Visions of the Chinese Diaspora", p. 179-210.

Archipel 28, 1984, C. S., "Chinese Women Writers in Indonesia and their Views of Female Emancipation", p. 149-171.

—, Wong Seng-tong, "The Development of Malaysia's Colloquial Chinese Literature (19191941)", p. 173-204. 
Archipel 30, 1985 D. L. et C. S., «Islam et sinité », p. 73-94.

Archipel 32, 1986, C. S., " L'édition chinoise dans le monde insulindien (fin XIX ${ }^{\mathrm{e}}$ - début $\mathrm{XX}^{\mathrm{e}}$ s.) », p. 113-139.

- , Antonio S. Tan, "The Chinese Mestizos and the Formation of the Filipino Nationality", p. 141-162.

-, Yong Ching Fatt, “'Nanyang Chinese Patriotism towards China Knows no Political Boundaries': The Case of Tan Kah Kee (1874-1961)", p. 163-181.

Archipel 33, 1987, C. S. et D. L., « À propos de la visite à Java d'une escadre impériale chinoise en $1907 »$ p. 79-115.

Archipel 34, 1987, Liang Liji, "Sastra Peranakan Tionghoa dan Kehadirannya dalam Sastra Sunda", p. 165-179.

—, Dédé Oetomo, "Serat Ang Dok: A Confucian Treatise in Javanese", p. 181-197.

Archipel 37, 1989, Ann Kumar, “A Swedish View of Batavia in 1783-4: Hornstedt's Letters”, p. $247-262$.

-, C. S., « Commerces ambulants et insertion sociale à Surabaya, vers la fin du XIX ${ }^{\mathrm{e}}$ siècle », p. 297-326.

Archipel 38, 1989, Charles A. Coppel, “'Is Confucianism a Religion?' A 1923 Debate in Java”, p. $125-135$.

Archipel 39, 1990, Claude Guillot, Lukman Nurhakim, C. S., « Les Sucriers chinois de Kelapadua, Banten XVII ${ }^{\mathrm{e}}$ s. », p. 139-158.

—, 1990, Michael R. Godley \& Charles A. Coppel, "The Pied Piper and Prodigal Children. A Report on the Indonesian-Chinese students who went to Mao's China", p. 179-198.

Archipel 41, 1991, C. S., "The Han Family of East Java. Entrepreneurship and Politics $\left(18^{\text {th }}-\right.$ $19^{\text {th }}$ Centuries)", p. 53-87.

Archipel 42, 1991, Faye Yik-wei Chan, "Mrs Tjoa Hin Hoeij (1907-1990): Profile of an Enterprising Peranakan Chinese Woman Writer in Late Colonial Indonesia", p. 23-27.

—, Chen Dasheng «Une pierre tombale du début du XIVe siècle retrouvée à Brunei », p. 47-52.

-, Tan Chee Beng, "A Note on the Orang Yunnan in Terengganu”, p. 93-120.

Archipel 43, 1992, David K.Y. Chng, "The Yuenan youji, A Rare book Published in Singapore (1888)", p. 131-137.

—, C. S., « Regard d'un Peranakan de Singapour sur le Vietnam (1888) », p. 139-144.

-, Tan Keong Sum, « Récit d'un voyage au Viêtnam », traduit du chinois et annoté par C. S, p. 145-166.

Archipel 47, 1994, C. S. et Ta Trong Hiêp, « De Batavia à Saïgon - Notes de voyage d'un marchand chinois de Batavia (1890)», p. 155-192.

Archipel 48, 1994, Monique Zaini Lajoubert, « Le Syair Cerita Siti Akbari de Lie Kim Hok (1884) ou un avatar du Syair Abdul Muluk (1846) », p. 103-124.

-, C. S., «Aux origines du roman malais moderne: Tjhit Liap Seng ou «Les Pleïades», de Lie Kim Hok (1886-87) », p. 128-156.

-, Myra Sidharta, “Asmaraman Sukowati Kho Ping Hoo (b. 1926): Writer of Cloak-anddagger Stories in Indonesia", p. 157-176.

Archipel 49, 1995, Faye Yik-Wei Chan, "Chinese women's emancipation as reflected in two Peranakan journals (c. 1927-1942)", p. 45-62.

Archipel 50, 1995, C. S., « Le cimetière chinois de Kasunyatan (Banten Lama) - fin XVII début XVIII' s. », p. 41-66. 
Archipel 51, 1996, Paul Piollet, Commentaire de C. S. \& D.L « Une culture révolue ? Le Pasisir javanais de Gresik à Rembang », p. 95-112.

Archipel 52, 1996, Chen Jiarong, « À la recherche du «Récit sommaire sur Batavia» Bayou jilüe de Chen Hongzhao » (traduit par C. S.), p. 19-30.

Archipel 53, 1997, C. S., « La communauté chinoise de Surabaya. Essai d'histoire, des origines à la crise de $1930 »$, p. 121-206.

Archipel 54, 1997, C. S., « Le voyage du marchand Tan Hoe Lo à Paris (1889)», p. 177-188.

Archipel 56, 1998, C. S., « Sur les traces de la diaspora des Baba des Détroits : Li Qinghui et son "Récit sommaire d'un voyage vers l'Est" », p. 71-120.

- A. Lombard Jourdan, C. S., « Les Chinois de Kupang (Timor) aux alentours de 1800 », p. 393-428.

Archipel 58, 1999, L. Blussé, "Chinese Century. The Eighteenth Century in the China Sea Region", p. 107-129.

—, Danny Wong Tze-Ken, "Chinese Migration to Sabah before the Second World War", p. 131-158.

Archipel 60, 2000, C. S. and Myra Sidharta, "The Hainanese of Bali: A Little Known Community", p. 87-124.

Archipel 61, 2001, « Les Hainanais de Malaisie en quête de leur histoire et de leur identité », p. 196-201.

Archipel 62, 2001, Han Bing Siong, "A Short Note on a few Uncertain Links in the Han Lineage", p. 43-52.

-, C. S., "Some more Comments on Uncertain Links in the Han Lineage", p. 53-64.

Archipel 63, 2002, C. S., " Srivijaya, la Chine et les marchands chinois ( $\mathrm{X}^{\mathrm{e}}-\mathrm{XII}{ }^{\mathrm{e}} \mathrm{s}$.) », p. 57-78.

Archipel 66, 2003, C. S., "A Tentative Interpretation of the Chinese Inscription (1231) Engraved on a Bronze Gong Recovered in Muara Jambi (Central Sumatra)", p. 91-112.

-, Henri Chambert-Loir \& Marie-France Dupoizat, « Les jarres de Bornéo d'après un texte malais de $1839 »$, p. 113-160.

Archipel 68, 2004, Peter Worsley, “Gouw Peng Liang's Novella Lo Fen Koei”, p. 241-272.

-, C. S., "The Han Family from the Residency of Besuki", p. 273-287.

Archipel 72, 2006, C. S., "Women's Social Status as Reflected in Chinese Epigrahs from Insulinde (16 ${ }^{\text {th }}-20^{\text {th }}$ Centuries)", p. 157-194.

-, C. S. \& Myra Sidharta, "The Manufacture of Gravestones in Indonesia - A Preliminary Report", p. 195-220.

Archipel 73, 2007, C. S., "Cultural Links between Insulindian Chinese and Fujian as Reflected in Two Late $17^{\text {th }}$-Century Epigraphs", p. 167-194.

Archipel 74, 2007, C. S. and Myra Sidharta, "Traditional Chinese Medicine and Pharmacy in Indonesia: Some Sidelights", p. 165-204.

Archipel 76, 2008, C. S., "The Chinese Origin of the Muara Jambi Gong as Evidenced by a New Archaeological Find", p. 7-14.

-, C. S., « Le goût chinois pour les nids de salanganes et ses répercussions économiques en Indonésie (XVe/XVI ${ }^{\mathrm{e}} \mathrm{s}-\mathrm{XXI}{ }^{\mathrm{e}}$ s. », p. 251-290.

-, Neil Khor, "Malacca's Straits Chinese Anglophone Poets and their Experience of Malaysian Nationalism", p. 127-149. 
Archipel 77, 2009, Koos Kuiper, « Du nouveau sur la mystérieuse mission de Batavia à Saïgon en $1890 »$, p. 27-44.

-, Mary Somers Heidhues, "1740 and the Chinese Massacre in Batavia: Some German Eyewitness Accounts", p. 117-147.

-, C. S., "The Massacre of the Chinese as Reflected in a Contemporary Chinese Narrative", p. $149-154$.

Archipel 78, 2009, C. S., "Malay and Javanese Loan-words in Chinese as a Mirror of Cultural Exchanges", p. 181-208.

Archipel 82, 2011, M. S. de Vienne, "The Chinese in Brunei: From Ceramics to Oil Rent", p. 25-48.

—, Yerry Wirawan, "Pers Tionghoa Makassar Sebelum Perang Dunia Kedua", p. 49-82.

-, Elisabeth Chandra, "Fantasizing Chinese/Indonesian Hero: Njoo Cheong Seng and the Gagalkodra Series", p. 83-113.

Archipel 84, 2012, Danny Wong Tze Ken, "A Hibrid Community in East Malaysia: The SinoKadazans of Sabah", p. 107-127.

Archipel 87, 2014, "Wong Yee Tuan \& Lee Kam Hing, "Aceh-Penang Maritime Trade and Chinese Mercantile Networks in the Nineteenth Century", p. 173-202.

Archipel 92, 2016, Chinese Deathscapes in Insulindia,

—, C. S., "Introduction", p. 3-8.

-, Danny Wong Tze Ken, "Early Chinese Cemeteries in Malaysia as Reflected by Three Cemeteries ( $17^{\text {th }}-19^{\text {th }}$ centuries)", p. 9-21.

- C. S., "Ancient Chinese Cemeteries of Indonesia as Vanishing Landmarks of the Past", p. 23-61.

-, Richard T. Chu and Teresita Ang See, "Toward a History of Chinese Burial Grounds in Manila during the Spanish Colonial Period", p. 63-90.

—, Lee Kam Hing, "State Policy, Community Identity, and Management of Chinese Cemeteries in Colonial Malaysia", p. 91-110.

—, Erik Akpedonu, "The Manila Chinese Cemetery: A Repository of Tsinoy Culture and Identity", p. 111-153.

—, Catherine Guéguen. "The Chinese Cemeteries in the Philippines: Immobile Spaces?", p. $155-176$.

—, C. S., "From Cemeteries to Luxurious Memorial Parks. With Special Reference to Malaysia and Indonesia", p. 177-212.

Archipel 93, 2017, Song Ge, « Note sur le musée bibliothèque des Chinois peranakan de Tangerang », p. 219-228.

Archipel 97, 2019, Song Ge, "Sam Kok, presse et idée de nation chinoise aux Indes néerlandaises (fin XIX ${ }^{\mathrm{e}}$-début $\mathrm{XX}^{\mathrm{e}}$ s.) », p. 213-240.

Archipel 100, 2020, C. S., "Of the Use of Calligraphy in Sino-Javanese Communities $\left(18^{\text {th }}\right.$ Early $21^{\text {st }}$ Centuries)", p. 143-174.

- Jack Meng-Tat Chia, "Singing to Buddha: The case of a Buddhist Rock Band in Islamic Indonesia", p. 175-198. 
